\title{
MORPHOLOGIC EFFECTS OF HYPERVITAMINOSIS A ON RAT SUBMANDIBULAR GLAND
}

\author{
J. A. Regezi and N. H. Rowe \\ Departments of Oral Pathology, David Grant USAF Medical Center, Travis Air \\ Force Base, California, 94535, and University of Michigan School of Dentistry, \\ Ann Arbor, Michigan, 48104, U.S.A.
}

\begin{abstract}
Summary-Young male Sprague-Dawley rats were fed oral supplements of vitamin A; either a subtoxic dose of 5000 i.u./day for 16 weeks (10 animals), or a toxic dose of 15,000 i.u./day for 16 days (5 animals). High-dose animals exhibited signs of acute toxicity; low-dose animals demonstrated only less weight gain than controls. Vitamin A sera and liver levels evidenced intoxication. Light and electron microscopy were conducted upon acini, intercalated ducts, and striated-granular ducts of the submandibular gland. Acinar cells evidenced rough endoplasmic reticulum clefting and hyperplasia of both rough endoplasmic reticulum and Golgi apparatus similar to changes produced by pilocarpine or isoproterenol and interpreted as hyperactivity. Also increased were the number of degenerating acinar cells. Striated-granular duct cells were similar to controls except for increased cellular degeneration. Intercalated ducts appeared unaffected. Abnormalities were more pronounced in short-term, toxic hypervitaminosis $A$ than long-term, subtoxic hypervitaminosis A.
\end{abstract}

\section{INTRODUCTION}

Vitamin A has several dose-dependent effects on epithelial cells. Deficient levels cause cells that normally produce mucin to form keratin (NIELSEN et al., 1966; PARNeLL and SHERMAN, 1962; WolbaCH and Howe, 1925). Excess vitamin A has an antikeratinizing effect on epithelial cells, and in sufficiently high doses causes mucous metaplasia of keratinizing epithelium (BERN et al., 1955; BERN and LAWRENCE, 1962; HARDY, 1968; JACKSON and Fell, 1963; LawrenCE and BerN, 1961; New, 1963). Increase as well as decrease of mitotic activity in epithelia has been reported to be vitamin A dependent (LAWRENCE and BERN, 1958; SHERMAN, 1961).

Previous studies of the effect of vitamin A upon salivary gland epithelia have been limited to deficiency. As in other epithelia, squamous metaplasia with keratin production by ductal cells was demonstrated (HAYES, MCCOMBS and FAHERTY, 1970; PARnelL and Sherman, 1962; Trowbridge, 1969). Also in vitamin A deficiency, potentiation of chemically induced salivary gland neoplasia has been described (RowE et al., 1970). What effect excess vitamin A might have on cells of salivary gland tissue has not been reported.

\section{MATERIALS AND METHODS}

In the first of 2 investigations, long-term, subtoxic doses of vitamin A were used to produce hypervitaminosis. Twenty male Sprague-Dawley rats weighing $81 \pm 2 \mathrm{~g}$ were separated into 2 equal groups (A and B). Group A rats were fed 10,000 i.u. of vitamin A (Aquasol A USV Pharmaceutica) orally once every 2 days; group B served as controls. All were fed Purina laboratory chow and water 
ad libitum and weighed bi-weekly. Animals, 6 per cage, were maintained in a constant temperature and humidity environment. Animals were terminated after an experimental period of 16 weeks.

In the second investigation, short-term, toxic doses of vitamin A wcre used. Ten male SpragueDawley rats weighing $110 \pm 4 \mathrm{~g}$ were randomly separated into 2 equal groups (C and D). Group $\mathrm{C}$ rats were fed 50,000 i.u. of vitamin A orally per day; group D rats served as controls. Diets and environmental conditions were otherwise identical to those for groups A and B. Animals were weighed every 4 days and terminated at the end of 16 days.

At termination, the submandibular glands of experimental and control animals were exposed through a ventral incision. The posterior half of the left gland was excised and immediately placed in fresh 3 per cent glutaraldehyde and fixed for $2 \mathrm{hr}$ at $4^{\circ} \mathrm{C}$. Tissue was rinsed in phosphate buffer, post-fixed in 1 per cent osmium tetroxide in veronal buffer, washed with distilled water, dehydrated in a graded series of ethanol, and embedded in Epon 811 . Sections of 600-900 nm thickness were cut with glass knives on a Sorvall Porter-Blum MT-w ultra-microtome, double-stained with 7.6 per cent uranyl acetate in distilled water and Millonig's lead stain, examined and photographed in a Zeiss $9 \mathrm{~S}$ electron microscope (PEASE, 1964).

Thick sections for light microscopy were also cut from the Epon blocks for purposes of orientation and correlation. Sections $0 \cdot 5-1 \cdot 0 \mu \mathrm{m}$ thick were mounted on glass slides and stained with a 1 per cent solution of toluidine blue, saturated with sodium borate.

The right and the remaining halves of the left submandibular glands were fixed in 10 per cent formalin and processed by standard histologic techniques for light microscopy.

Livers from 3 rats in each group were removed, pooled, and frozen for laboratory analysis of vitamin A (Younger Laboratories, 123 Cliff Cave Road, St. Louis, Missouri). Also for each group, $3 \mathrm{ml}$ of blood from each of 3 rats was obtained by intracardiac aspiration, pooled, and serum vitamin A determined (Bio-Science Laboratories, 7600 Tyrone Avenue, Van Nuys, California).

\section{RESULTS}

\section{Biochemical determinations}

Serum vitamin A determinations were made using the method of Sobel and SNow (1947). Groups A and B sera showed no difference in vitamin A levels, while group C was more than 16 times that of group D.

Liver determinations of vitamin A were made using the method of DANN and EVELYN (1938). The experimental groups A and C showed remarkably high levels of vitamin A compared to their respective controls (Table 1).

\begin{tabular}{|c|c|c|}
\hline Group & $\begin{array}{c}\text { Serum } \\
\text { (i.u. } \mathbf{A} / 100 \mathrm{ml} \text { ) }\end{array}$ & $\begin{array}{c}\text { Liver } \\
\text { (i.u. A/g) }\end{array}$ \\
\hline $\begin{array}{l}\mathrm{A} \\
\mathrm{B} \\
\mathrm{C} \\
\mathrm{D}\end{array}$ & $\begin{array}{r}15 \\
15 \\
5097 \\
311\end{array}$ & $\begin{array}{r}14,310 \\
36 \\
39,861 \\
621\end{array}$ \\
\hline
\end{tabular}

\section{Gross observations}

Rats of group A showed less weight gain per unit time than controls, and began to lose weight at the fourteenth experimental week. The difference in mean weights between groups A and B was not statistically significant until the sixteenth week $(p<0 \cdot 01)$.

Rats of group C (Short-term, toxic hypervitaminosis) initially showed arrested growth followed by progressive weight loss. A significant difference in mean weights was apparent by day $6(p<0 \cdot 01)$. Controls exhibited a steady rapid weight gain. 
Rats of group A appeared only slightly smaller in size than the group B rats by the end of the sixteenth week. Animals from groups A and B were normal in appearance and behaviour. Group $C$ rats appeared lethargic, inactive, and smaller than controls. Hair loss occurred primarily around the mouth and continued caudally along the ventral surface. Elsewhere, fur was dull, matted, and shaggy.

\section{Microscopic observations}

Intralobular parenchyma (acini, intercalated ducts, and striated-granular ducts) were studied. Submandibular glands of control rats appeared as described in the literature (JACOBY and LeESON, 1959; LeESON and JACOBY, 1959; SCOTT and PeASE, 1959; TAMARIN and SReEbnY, 1965).

Frequent "washed out" appearing or degenerating acinar cells were seen in the submandibular glands of group A. Similar cells were also apparent in group C, but were less frequent. These cells, with light microscopy, exhibited dark fibrillar material set in a lighter cytoplasmic background (Fig. 1). Ultrastructurally they contained damaged rough endoplasmic reticulum, some evidence of residual Golgi vesicles, and a few irregularly shaped mucin granules. The disrupted organelles were found in a light-staining cytoplasm that was the same electron density as the acinar lumina (Fig. 2). Desmosomal attachments could be seen between these and normal neighbouring cells. Degenerating cells were infrequently seen in controls. A few striatedgranular duct cells showed features of degeneration in the form of dilated rough endoplasmic reticulum cisternae, distorted organelles, and shrunken, irregular nuclei (Fig. 3).

Except for degenerative changes, acini of group $\mathrm{C}$ consistently exhibited more exaggerated alterations than group A. Acinar cells demonstrated enlarged ergastoplasmic areas. These areas appeared thickened and widened across the base and had many spindle-shaped, parallel clefts, evident to some degree in all cells (Fig. 4). Many acinar nuclei appeared larger than normal with prominent nucleoli and dense peripheral chromatin rings. Ultrastructurally, acinar cells displayed hyperplastic rough endoplasmic reticulum and clefting (Figs. 5 and 6). Acinar lumina and intercellular canaliculi were readily found due to dilatation and relative electron-lucency when compared to adjacent mucin granules (Fig. 7).

Intercalated duct cells were similar to controls. Granular duct cells were comparable to controls, except for some cells in group $\mathrm{C}$ which had a few small zymogen granules indicating immaturity. Striated ducts resembled controls except for the occasional degenerating ductal cells previously noted.

There was no evidence of mucous metaplasia in the intralobular ductal epithelium of either experimental group. Also, there was no change in the appearance of the mucin granules in the acinar cells in either treatment group.

\section{DISCUSSION}

Differences in animal age, route of administration, and typc of vitamin A (i.c. mammal liver, emulsions, synthetic) are unimportant in the production of hypervitaminosis A (RODAHL, 1950). What remains for clarification are the time-dose 
relationships. Vitamin A levels used in this study were based on previously reported studies (BRENNER and Brooks, 1942; LeWIS et al., 1942; MisRA, 1968; RODAHL, 1950).

Confirmation that hypervitaminosis A occurred was made by serum and liver Vitamin A determinations. Values reported elsewhere as normal for vitamin $\Lambda$ content range from 8.5 to $112 \mathrm{i} . u$./ $100 \mathrm{ml}$ of serum, and from 27 to $113 \mathrm{i} . \mathrm{u}$./g of liver (BRENNER and Brooks, 1942; Glover, Goodwin and Morton, 1947; Lewis et al., 1942). Although both groups A (long-term, subtoxic hypervitaminosis) and B (control) had similar normal serum values, liver values differed significantly, which indicated that group A rats were hypervitaminotic. The modest transient elevations of serum vitamin $A$ over the 16-week experimental period had resulted in storage of excess vitamin A. Both serum and liver vitamin A in group C (short-term, toxic hypervitaminosis) were markedly elevated. The more frequent higher doses administered to animals in this group had resulted in incomplete serum clearance despite increased liver storage of absorbed vitamin A. It has been shown that normally the serum level of vitamin A is maintained relatively constant and does not reflect the liver store (BrenNer and Brooks, 1942; Glover et al., 1947). Also no direct relationship has been demonstrated between severity of clinical symptoms and serum levels (RoDAHL, 1950). Thus, liver values rather than serum content provide the better indicator of vitamin A deficiency or intoxication.

The observed alterations (hyperplastic and hypertrophied Golgi apparatus and rough endoplasmic reticulum, clefting of rough endoplasmic reticulum, premature granule formation, and dilated, electron-lucent acinar luminal spaces) are interpreted to indicate acinar hyperactivity. Catecholamines administered to rats resulted in salivary gland enlargement due to hypertrophy and hyperplasia of acinar cells and their ergastoplasm; features indicative of increased protein synthesis (Ронто, 1966). Ultrastructural changes in the submandibular gland of the rat following isoproterenol administration included hypertrophic rough endoplasmic reticulum and Golgi apparatus, increased numbers of ribosomes, dilatation of secretory canaliculi, swollen nuclei and enlarged nucleoli (KANDA, MAYFIELD and GHIDONI, 1968; TAKAHAMA and BARKA, 1967). It was concluded that isoproterenol stimulated salivary secretions, DNA synthesis and mitotic activity. Pilocarpine administration increased both PAS staining and salivation (BIXLER, WEBSTER and MUHLER, 1958). Increased secretory activity was obtained in another study by the techniques of fasting-refeeding, pilocarpine, and electrical stimulation. Results, most dramatic to pilocarpine, were hyperplasia and hypertrophy of acinar RER and Golgi apparatus. Whorls and cisternal dilatations of rough endoplasmic reticulum were also seen (SCOTT and PEASE, 1964).

The degenerating acinar cells and disrupted ductal cells observed in both experimental groups contained fragmented and disoriented organelles. Similar-appearing cells have been reported in the pancreas following injections of ethionine (FITZGERALD and Herman, 1965). Rough endoplasmic reticulum disruption, acinar vacuolization, loss of ribosomes from rough endoplasmic reticulum, and cytoplasmic debris were observed. These features were interpreted as degenerative changes. Similar changes have been reported in liver cells following treatment with carbon tetrachloride (CHRIS- 


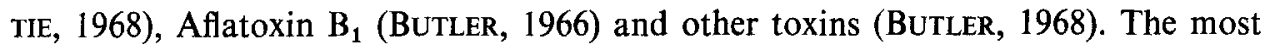
consistent features were disruption of rough endoplasmic reticulum, dilatation of rough endoplasmic reticulum cisternae and Golgi apparatus, and mitochondrial swelling. Increased incidence of degenerating cells in a hyperactive gland suggest premature cell death from overwork or exhaustion. It is also possible that degeneration was due to an intracellular action of vitamin A. It is known that excess vitamin A causes increased cell and organelle membrane permeability (BELANGER and CLARK, 1967; DingLE, 1961; Dingle, LUCY and Fell, 1961). This could have been responsible for release of lysomal enzymes with subsequent autolysis.

Vitamin A does not produce morphologic evidence of altered protein metabolism in ductal cells. It can, however, be added to the list of agents that cause acinar hyperactivity. It was not determined whether the submandibular gland was directly or indirectly affected by vitamin A, nor what effect its administration had on other organs. The possibility must be considered that the alterations observed were a reflection of injury to, or stress upon, another organ or organs which secondarily affected cells of the submandibular gland.

Acknowledgement-This project was supported through funds from the NIH under NIDR training grant DE00013, 040450. We are indebted to Dr. D. BAIC, Dept. of Zoology, University of Michigan for his assistance and the use of his laboratory. The opinions contained in this paper are those of the authors and are not to be construed as official or reflecting the view of the Department of the Air Force or of the Air Force Medical Service at large.

Résumé-De jeunes rats mâles Sprague-Dawley ont reçu per os de la vitamine A, soit une dose sub-toxique de 5000 i.u./jour pendant 16 semaines ( 10 animaux), soit une dose toxique de 15.000 i.u./pendant 16 jours ( 5 animaux). Ces derniers présentent des signes d'intoxication aigue: alors que le premier groupe ne présente qu'une perte de poids par rapport aux témoins. Les taux en vitamine $\mathrm{A}$ du sérum et du foie témoignent de l'intoxication. Des examens de microscopie classique et électronique ont été réalisés au niveau des acini, des canalicules intercalaires et des canalicules striés et granulaires de la glande sous-maxillaire. Les cellules acineuses présentent des ruptures de l'ergastoplasme ainsi qu'une hyperplasie de ce dernier et de l'appareil de Golgi. Ces lésions, identiques à celles provoquées par la pilocarpine ou l'isoproténerol, témoignent d'une hyperactivité. Le nombre des cellules acineuses dégénérées est aussi augmentée. Les cellules des canalicules striés et granulaires paraissent intactes. Les anomalies sont plus apparentes au cours de l'hypervitaminose A toxique, provoquée rapidement que par hypervitaminose $A$ prolongée avec des doses sub-toxiques.

Zusammenfassung-Junge Sprague-Dawley Ratten, männlichen Geschlechts, erhielten mit ihrer Nahrung einen Zusatz an Vitamin A: einerseits eine subtoxische Dosis von 5000 i.u./Tag, während 16 Wochen (10 Tiere), andererseits eine toxische Dosis von $15.000 \mathrm{i}$.u./Tag, während 16 Tagen ( 5 Tiere). Bei den letzteren treten akute Vergiftungserscheinungen auf, während die erste Gruppe nur einen Gewichtsverlust, gegenüber den Test-Tieren zu verzeichnen hat. Der Gehalt an Vitamin A, von Serum und Leber kann als Reweis für die Vergiftung betrachtet werden. Am klassischen und elektronischen Mikroskop, werden über die Acini, die Zwischenkanälchen, die striierten und granular Kanaälchen der Unterkieferspeicheldrüse Untersuchungen vorgenommen. Die Zellen der Acinus lassen Zerreissungen des endoplasmatischen Retikulums erkennen, sowie cine Hyperplasie derselben und auch des Golgi Apparates. Die Gewebsveränderungen, 
die identisch sind mit denen die durch Pilocarpin oder Isoprotenerol entstehen, sind der Beweis einer Úberaktivität. Die Anzahl der degenerierten Zellen der Acinis ist auch erhöht, während diejenigen der striierten und granular Kanälchen intakt zu sein scheinen. Die aufgetretenen Anomalien kommen offensichtlicher zum Vorschein im Verlauf der schnell provozierten toxischen Hypervitaminose A, als bei der, auf längerer Sicht, hervorgerufenen sub-toxischen Hypervitaminose A.

\section{REFERENCES}

Belanger, L. and Clark, I. 1967. Alpharadiographic and histological observations on the skeletal effects of hypervitaminosis A and D in the rat. Anat. Rec. 158, 443-451.

Bern, H. A., Elias, R., Pickett, L., Powers, G. and Harkness, H. 1955. The influence of vitamin A on the epidermis. Am. J. Anat. 96, 419-447.

Bern, H. A. and LAWrence, D. J. 1962. Fundamentals of Keratinization, a Symposium (edited by Butcher, E. O. and Sognnaes, R.F.), Pub. No. 70, pp. 95-112. Am. Ass. Adv. Science, Wash., D.Cl

Bixler, D., Webster, R. and Muhler, J. C. 1958. The effect of pilocarpin on the submaxillary gland of the rat. J. dent. Res. 37, 649-653.

Brenner, S. and Brooks, M. C. 1942. The relation of liver stores to the occurrence of early signs of vitamin A deficiency in the white rat. $J$. Nut. 23, 459-456.

BUtLER, W. H. 1966. Early hepatic parenchyma changes induced in the rat by aflatoxin B1. Am. J. Path. 49, 113-128.

BUtLeR, W. H. 1968. Early electron microscopic changes in the course of liver injury. New Zeal.med.J. $67,18-25$.

CHRISTIE, G.S. 1968. Some aspects of carbon tetrachloride hepatotoxicity. New Zeal. Med. J. 67, 80-87.

DANN, W.J. and EvelYN, K. A. 1938. The determination of vitamin A with photo-electric colorimeter. Biochem.J. 32, 1008-1017.

DiNGLE, J. T. 1961. Studies on the mode of action of excess of vitamin A: release of bound protease by action of vitamin A. Biochem. J.79, 509-512.

Dingle, J. T., LuCY, J. A. and Fell, H. B. 1961. Studies on the mode of action of excess vitamin A: effect of excess vitamin $A$ on metabolism and composition of embryonic chick limb cartilage grown in organ culture. Biochem. J. 79, 497-500.

Fitzgerald, P. J. and Herman, L. 1965. Degeneration and regeneration of pancreas. Bull. N.Y. Acad. Med. 41, 804-810.

Glover, J., Goodwin, T. W. and Morton, R. A. 1947. Studics in vitamin A: the relationship between blood vitamin A levels and liver stores in rats. Biochem.J. 41, 97-99.

HARDY, M. H. 1968. Glandular metaplasia of hair follicles and other responses to vitamin A excess in cultures of rodent skin. J. Embryol. exp. Morph. 19, 157-180.

Hayes, K. C., MCCOMBS, H. L. and FaherTy, T. P. 1970. The fine structure of vitamin A deficiency: parotid duct metaplasia. Lab. Invest. 22, 81-89.

$J_{A C K S O N}$, S. F. and FELL, H. B. 1963. Epidermal fine structure in embryonic chick skin during atypical differentiation induced by vitamin $\Lambda$ in culture. Dev. Biol. 7, 394-419.

JACOBY, F. and LeEson, C. R. 1959. The postnatal development of the rat submaxillary gland. J. Anat. 93, 201-216.

Kanda, T., Mayfield, E. and Ghidoni, J. J. 1968. Ultrastructural alterations in the submaxillary acinar cells following isoproterenol administration: a new form of secretion granule. Exp. molec. Path. 9, 189-196.

LAWRENCE, D. J. and BERN, H. A. 1961. Mucous metaplasia and mucous gland formation in keratinized adult epithelium in situ treated with vitamin A. Exp. Cell Res. 21, 443-446.

LAWRENCE, D. and BERN, H. 1958. On the specificity of the response of mouse epidermis to vitamin A. J. invest. Derm. 31, 313-325.

LeESON, C. R. and JACOBY, F. 1959. An electron microscopic study of the rat submaxillary gland during its postnatal development and in the adult. J. Anat. 93, 287-295.

Lewis, J. M., Bodansky, O., Falk, K. G. and McGuire, G. 1942. Vitamin A requirements in the rat. J. Nut. 23, 351-363.

MisRA, U. K. 1968. Effect of hypervitaminosis A on rats: observations on growth and liver storage of vitamin A. Br.J. Nut. 22, 461-464.

NEw, D. A. 1963. Effects of excess vitamin A on cultures of skin and buccal epithelium of embryonic rat and mouse. Br.J. Derm. 75, 320-325. 
Nielsen, S. W., Mills, J., Rousseau, H. and Woefel, H. 1966. Parotid duct metaplasia in marginal bovine vitamin A deficiency. Am.J. Vit. Res. 27, 223-233.

Parnell, J. P. and Sherman, B. S. 1962. Fundamentals of Keratinization, a Symposium (edited by Butcher, E. O. and Sognnaes, R. F.), Pub. No. 70, pp. 113-131. Am. Ass. Adv. Science, Wash., D.C.

PeAse, D. C. 1964. Histological Techniques for Electron Microscopy. Academic Press, New York.

Poнто, P. 1966. Catecholamine induced salivary gland enlargement in rats. Acta odont. scand. 24, suppl. 45, 7-73.

RoDAHL, K. 1950. Hypervitaminosis A in the rat. J. Nut. 41, 399-421.

Rowe, N. H., Grammer, F. C., Watson, F. R. and Nickerson, N. H. 1970. A study of environmental influence upon salivary gland neoplasia in rats. Cancer 26, 436-444.

ScotT, B. L. and PeASE, D. 1959. Electron microscopy of salivary and lacrimal glands of the rat. Am. J. Anat. 104, 115-161.

Scott, B. L. and PeASE, D. 1964. In: Salivary Glands and their Secretions (edited by Sreebny, L. M. and MEYer, J.), pp. 13-44. MacMillan, New York.

Sherman, B. S. 1961. The effect of vitamin A on epithelial mitosis in vitro and in vivo. J. invest. Derm. $37,469-480$.

SoBEL, H. and SNOw, G. 1947. The estimation of serum vitamin A with activated glycerol dichlorohydrin. J. biol. Chem. 171, 617-632.

TAKAHAMA, M. and BARKA, T. 1967. Electron microscopic alterations of submaxillaty gland produced by isoproterenol. J. ultrastruct. Res. 17, 452-474.

TAmarin, A. and SReEBny, L. 1965. The rat submaxillary gland: a correlative study by light and electron microscopy. J. Morph. 117, 295-352.

Trowbridge, H. O. 1969. Salivary gland changes in vitamin A deficient rats. Archs oral Biol. 14, $891-900$.

Wolbach, S. B. and Howe, P. R. 1925. Tissue changes following deprivation of fat soluble vitamin A. J. exp. Med. 42, 753-778. 


\section{Plate 1}

FIG. 1. Epon-embedded section of submandibular gland acinus with a nucleated degenerating acinar cell. Toluidine blue. $\times 1000$

FIr. 2. Electron micrograph of cytoplasm of degenerating acinar cell showing damaged rough endoplasmic reticulum $(\mathrm{R})$, Golgi apparatus $(\mathrm{G})$, and mucin granules. Note acinar lumen with associated desmosomes (upper left corner). $\times 8000$

Fig. 3. Electron micrograph of degenerating striated-granular duct cell. Note damaged organelles. $\times 8000$ 

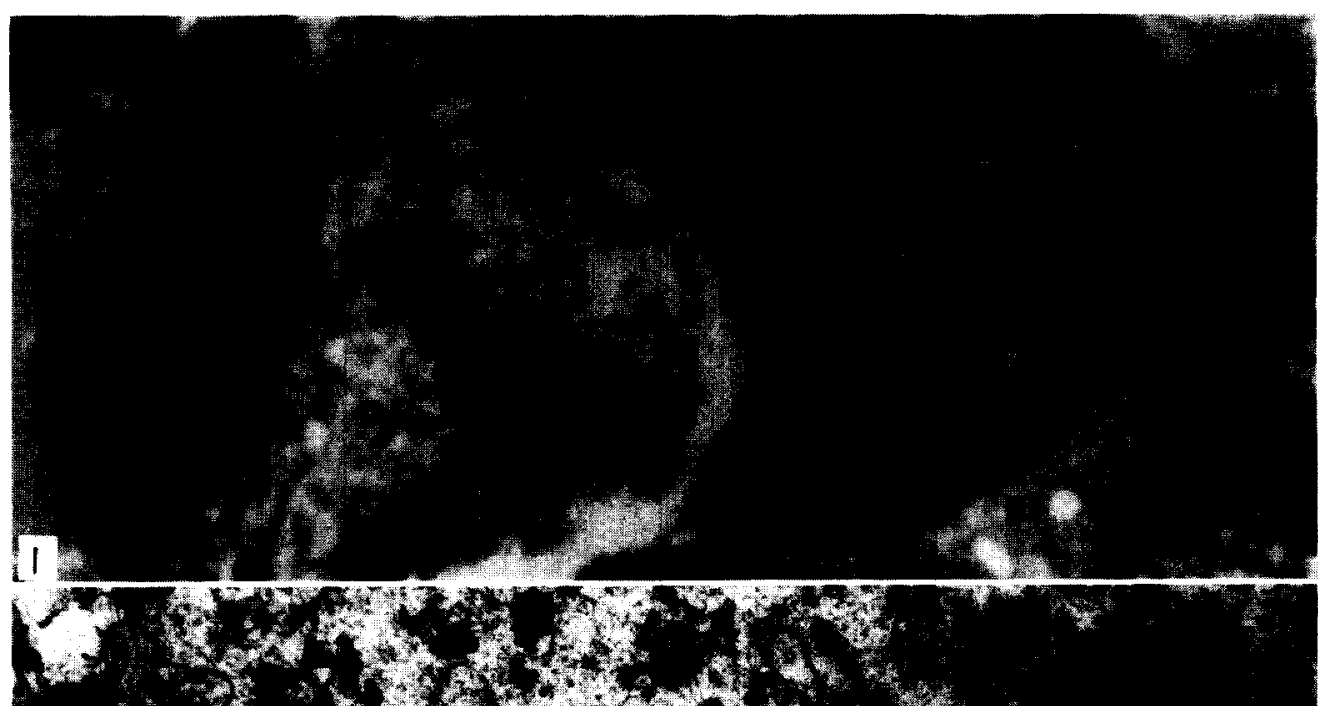

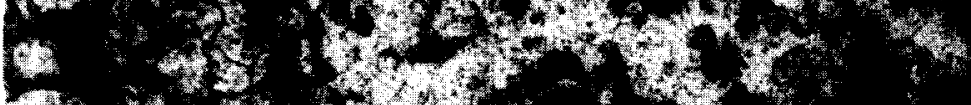

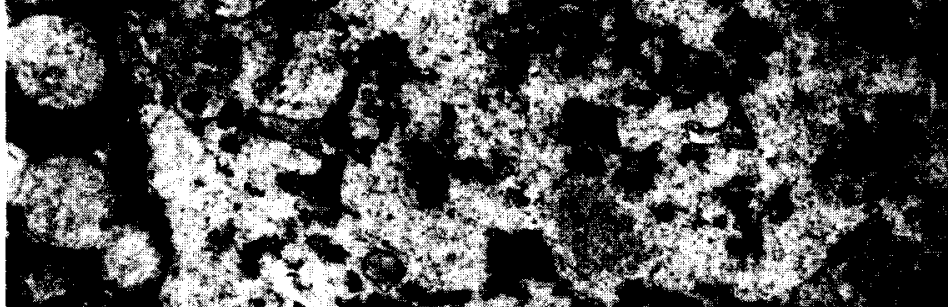

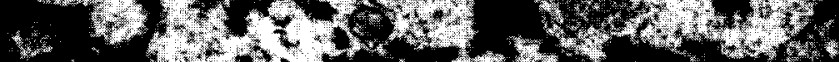

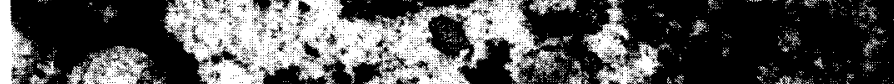

a hrots

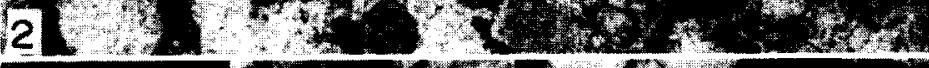

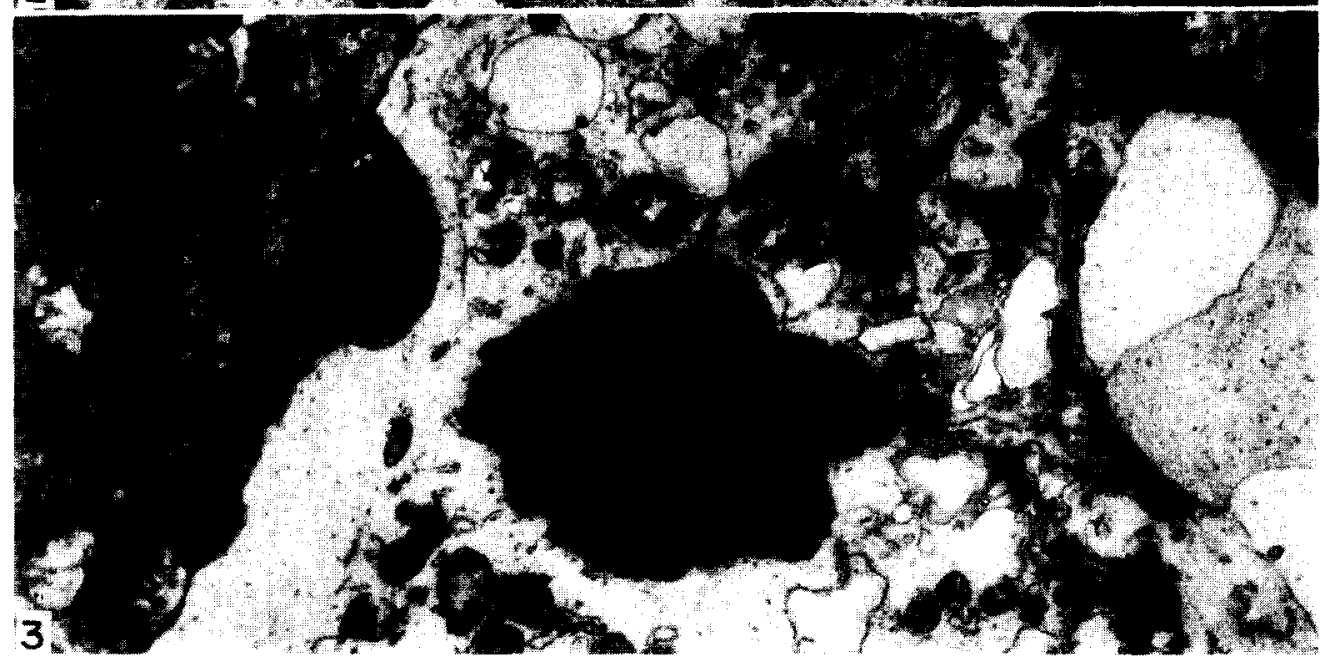


I. A. Regezi ANI N. H. Rowi:

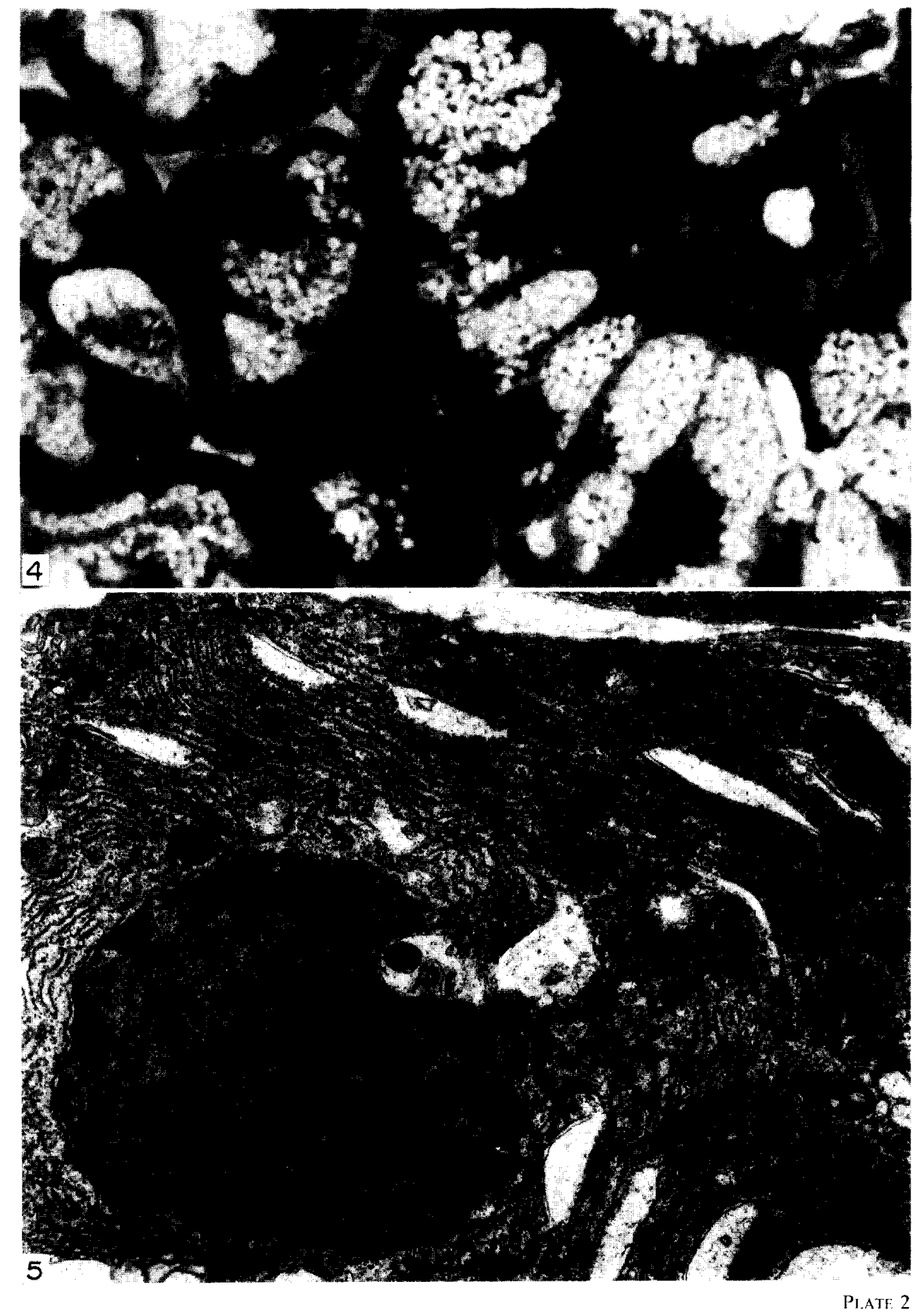




\section{Plate 2}

FIG. 4. Epon-embedded section of submandibular gland from short-term, toxic hypervitaminosis A rats. Note acinar cells with clefting of hyperplastic ergastoplasm, large nucleoli, enlarged acinar lumen (middle right) and degenerating acinar cell (middle left). $\times 1000$

Fig. 5. Electron-micrograph of short-term toxic hypervitaminosis A acinar cell. Note clefting of hyperplastic rough endoplasmic reticulum. $\times 12,000$ 


\section{Plate 3}

FIG. 6. High magnification electron-micrograph of hyperplastic acinar rough endoplasmic reticulum. Note clefting and Golgi apparatus (lower right) and nucleus (lower left). $\times 34,000$

Fig. 7. Electron-micrograph of acinus with enlarged electron lucent lumen and intercellular canaliculus (upper right). Note clefting of rough endoplasmic reticulum and prominent Golgi apparatus. $\times 7000$ 
EFFECTS OF HYPERVITAMINOSIS A ON SUBMANDIBULAR LILAND

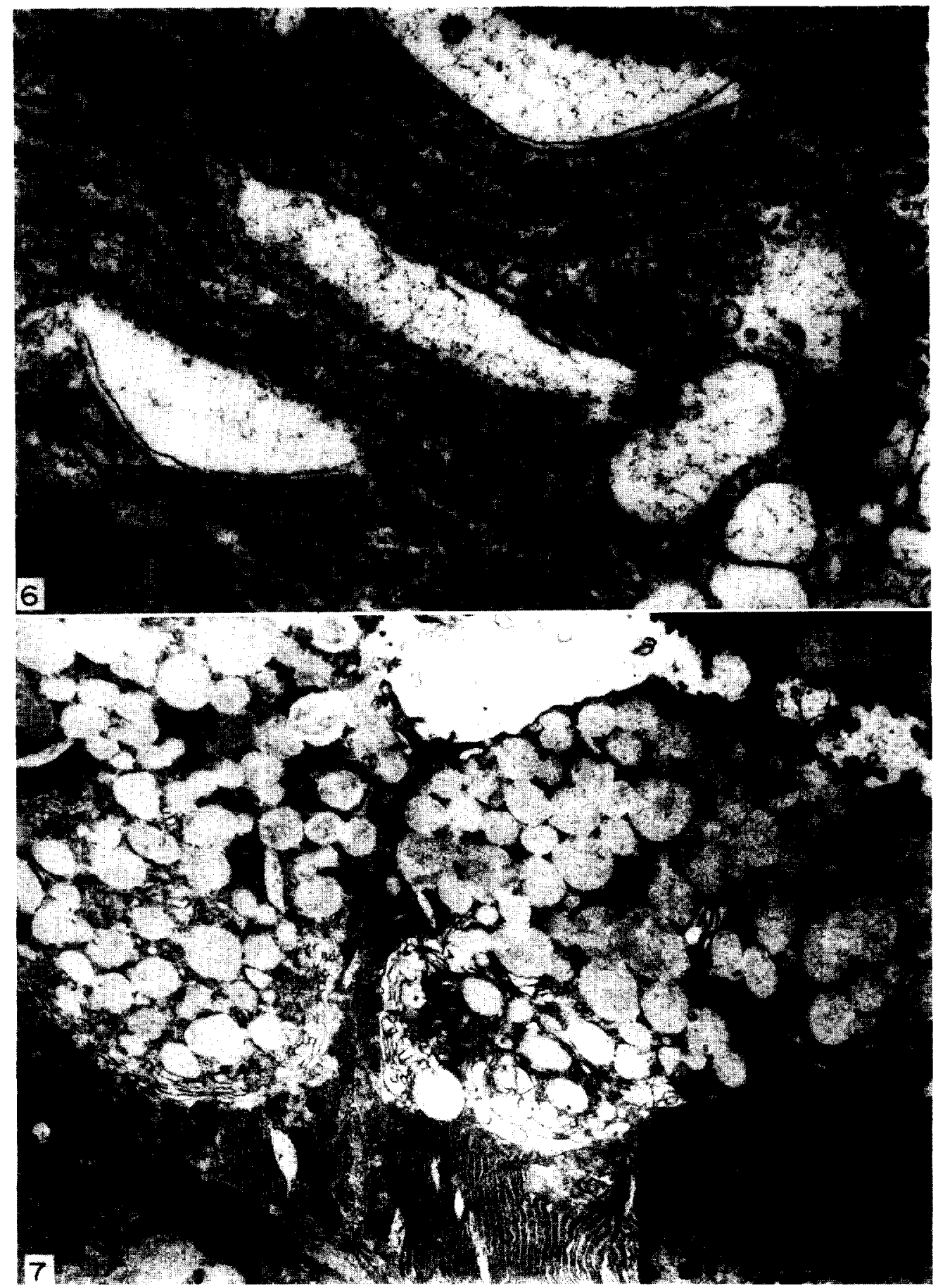

Plate 3

A.O.B. f.P. 1618 